\title{
Diagnostic accuracy of DNA methylation for head and neck cancer varies by sample type and number of markers tested
}

\author{
Xu Ji ${ }^{1}$, Chao Guan ${ }^{1}$, Xuejun Jiang ${ }^{1}$, Hong Li ${ }^{2}$ \\ ${ }^{1}$ Department of Otolaryngology, The First Affiliated Hospital of China Medical University, Shenyang, 110001, China \\ ${ }^{2}$ Department of Otorhinolaryngology Head and Neck Surgery, The Fourth Affiliated Hospital of China Medical University, \\ Shenyang, 110032, China \\ Correspondence to: Xuejun Jiang, email: djiangxj@163.com. \\ Hong Li, email: zhaohuan_2000@163.com.
}

Keywords: head and neck cancer, DNA methylation, diagnostic accuracy, biopsy type, meta-analysis

Received: March 27, 2016

Accepted: September 02, 2016

Published: September 23, 2016

\section{ABSTRACT}

\begin{abstract}
Abnormal methylation of certain cancer related genes strongly predicts a diagnosis of head and neck cancer (HNC), while the predictive power of methylation of other DNA markers for HNC remains unclear. To systemically assess the diagnostic value of DNA methylation patterns for HNC and the effect of methylation platform techniques and sample types, we performed a PubMed search for studies of the correlation between DNA methylation and HNC completed before July 2016, and extracted the sensitivity and specificity for methylated biomarkers. Across these studies, DNA methylation showed high sensitivity for diagnosing HNC in solid tissue (0.57), and high specificity in saliva (0.89). Area under the curve (AUC) from summary receiver operating characteristic (SROC) curves revealed that DNA methylation had more diagnostic power in solid tissue (AUC $=\mathbf{0 . 8 2}$ ) than saliva (AUC $=0.80$ ) or blood (AUC $=0.77$ ). Combinations of multiple methylated genes were more sensitive diagnostic markers than single methylated genes. Our results suggest that the diagnostic accuracy of methylated biomarkers for HNC varied by sample type and were most accurate when results from multiple sample types were considered.
\end{abstract}

\section{INTRODUCTION}

For this study, we selected from the literature reports of common squamous-cell carcinomas of the oral cavity, pharynx, and larynx (HSCC), which account for $90 \%$ of HNC [1]. Approximately 650,000 cases of HNC are identified per year [2] and the disease has high recurrence rates and poor prognoses due to distant metastasis [3]. Late diagnosis results in poorer prognosis [4]. Improved diagnostic accuracy for $\mathrm{HNC}$ could lead to earlier diagnosis, increasing patient survival rates.

Variations in the epigenetic modifications, such as DNA methylation in gene promoters, often inhibit gene transcription and protein translation, important factors in human carcinogenesis. A number of genes are frequently methylated in $\mathrm{HNC}$, including $p 16, D A P K 1$, and $R A S S F 1 A[5,6]$, or hypermethylated in $\mathrm{CpG}$ islands, such as $h M L H 1$ [7], KIF1A, and EDNRB [8]. Many groups have identified abnormally methylated genes as HNC diagnostic biomarkers but their predictive accuracies fluctuated among different sample types. Moreover, there are no systematic diagnostic accuracy studies or metaanalyses regarding the various sample types in HNC. We performed a systematic review and stratified metaanalysis of previous HNC studies based on sample types and diagnostic markers. We aim to provide more reliable evidence to clarify the diagnostic accuracy of DNA methylation markers, according to published reports that computed sensitivity and specificity.

\section{RESULTS}

Study characteristics

We identified 108 papers in a search of the PubMed database. Seventy-nine were excluded based on screening the title and abstract, including twenty-eight papers that did not involve $\mathrm{HNC}$, thirty-six papers that did not investigate the cancer diagnoses, eleven papers that did not include a diagnosis based on DNA methylation, and four reviews. We obtained the full texts of twentynine papers; of these five further papers were excluded, 
including two studies that did not show the sensitivity and specificity of the methylation biomarkers in a HNC diagnosis and three studies that only investigated the diagnosis of recurrence. We identified 183 studies from the remaining twenty-four articles [8-31] (Figure 1). In addition, we added 20 articles including 25 studies to our analysis from a review [32-51]. These studies were conducted in fifteen countries or regions (including the USA, Brazil, China, Hong Kong, Japan, Australia, Sweden, Egypt, Thailand, India, Taiwan, Hungary, Turkish, French and Italy) and were published between 2002 and 2016. The sample sizes of these studies ranged from 31-597 patients, with a mean of 115 .

The diagnostic accuracy of selected methylated genes was extracted from the included papers and grouped by sample type tested. Ten papers used saliva $[9,10,12,14,17$, $27,29,32,50]$, sixteen papers used solid tissue $[11,15,16$, $18,19,23-26,30,31,33-38,40-46,49]$, four papers used blood [21, 28, 31, 39], five papers used both solid tissue and saliva $[8,13,22,47,51]$, and two papers used both solid tissue and blood (Table 1) [20,33]. The studies evaluated the diagnostic power of methylation biomarkers as follows: thirty-five studies were based on a single gene [8, 12-14, $16-19,21,23,25-28,30,32-51]$, two papers were based on multiple genes $[9,22]$ and seven papers were based on both single and multiple genes [10, 11, 15, 20, 24, 29, 31]. The details of methylated biomarkers and their diagnostic powers are shown in Supplementary Table 1.

\section{Exploration of heterogeneity analysis}

To determine the effect model of diagnostic accuracy, we conducted heterogeneity tests for PLR, NLR, and DOR and found a significant heterogeneity of NLR in the solid tissue and saliva studies (Table 2). DOR showed no heterogeneity in the solid tissue or blood studies. PLR showed low heterogeneity in the solid tissue studies and no heterogeneity in the saliva or blood studies. The heterogeneity of NLR varied among the sample types.

We used meta-regression analysis to assess whether publication year, sample type, DNA methylation detection technique, or the methylation panel corresponding to single or multiple methylated biomarkers affected the diagnostic accuracy for HNC. The true and false positive rates were used as the responses in meta-regression analyses. As shown in Table 3, the $p$ values of sensitivity and false positive rates were not significant, suggesting that publication year, biomarker technique, and sample types did not affect the false positive rate.

\section{Meta-analysis and diagnostic accuracy}

The pooled sensitivity and specificity of metaanalysis was 0.52 (95\% CI $0.47-0.57)$ and 0.87 (95\% CI: 0.85-0.89), respectively. Meta-analysis was performed

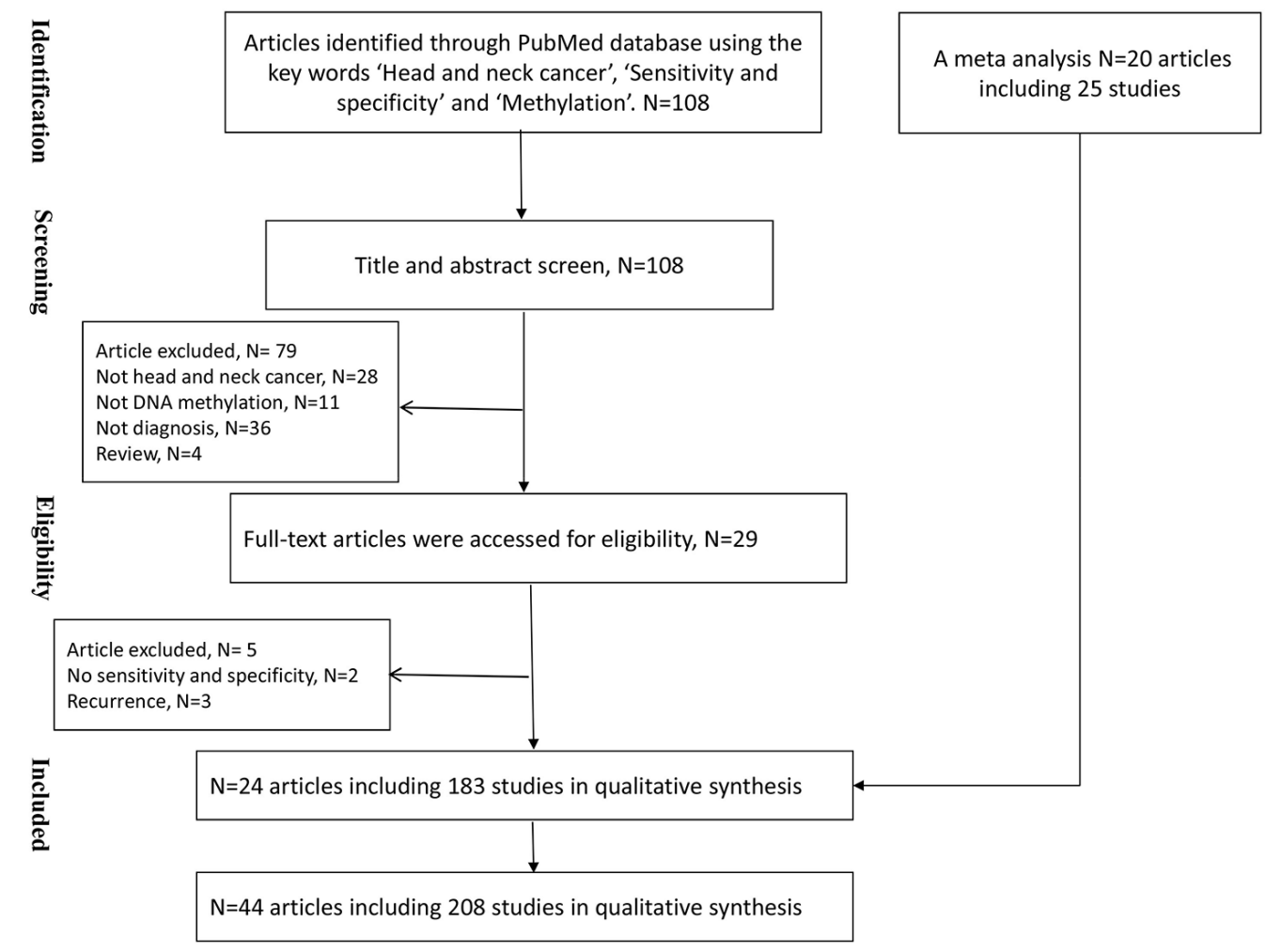

Figure 1: Flow chart showing the study retrieval process. 
Table 1: The included studies investigating the diagnosis of DNA methylation biomarkers in head and neck cancer

\begin{tabular}{|c|c|c|c|c|c|c|c|}
\hline Study & Country & Case\# & Control\# & Sample & Biomarker & Technique & Methylated genes \\
\hline Liu et al, 2016 & China & 246 & 246 & Tissue & $\mathrm{S}$ & BeadChip & S100A8 \\
\hline Nawaz et al, 2015 & Sweden & 44 & 18 & Tissue & $\mathrm{S}, \mathrm{M}$ & MSP & $\begin{array}{c}\text { EBNA1, LMP1, } \\
\text { RASSF1A, DAPK, } \\
\text { ITGA9, P16, } \\
\text { WNT7A, CHFR, } \\
\text { CYB5R2, WIF1, } \\
\text { RIZ1, FSTL1 }\end{array}$ \\
\hline Arantes et al, 2015 & Brazil & 40 & 40 & Saliva & $\mathrm{S}, \mathrm{M}$ & qMSP & $\begin{array}{l}\text { TIMP3, DCC, } \\
\text { DAPK, CCNA1, } \\
\text { AIM1, MGMT, } \\
\text { CDH1, HIC1 }\end{array}$ \\
\hline Kis et al, 2014 & Hungary & 60 & 68 & Saliva & $\mathrm{S}$ & MSP & P16 \\
\hline Bhatia et al, 2014 & India & 76 & 70 & Tissue, Blood & $\mathrm{S}$ & MSP & P16 \\
\hline Dang et al, 2013 & China & 12 & 30 & Tissue & $\mathrm{S}$ & MSP & P16 \\
\hline $\begin{array}{l}\text { Puttipanyalears } \\
2013\end{array}$ & Thailand & 88 & 161 & Saliva & $\mathrm{S}$ & COBRA & ALU \\
\hline Tian et al, 2013 & China & 40 & 41 & Blood & $\mathrm{S}$ & MSP & $\begin{array}{c}\text { RASSF1A, } \\
\text { CDKN2A, DLEC1, } \\
\text { DAPK1, UCHL1 }\end{array}$ \\
\hline Rettoriet al, 2013 & Brazil & 68 & 60 & Tissue & $\mathrm{S}$ & $\mathrm{BS}$ & $\begin{array}{l}\text { CCNA1, DAPK, } \\
\text { MGMT, SFRP1, } \\
\text { TIMP3 }\end{array}$ \\
\hline You et al, 2013 & China & 40 & 40 & Blood & $\mathrm{S}$ & MSP, BS & CDK10 \\
\hline $\begin{array}{l}\text { Schussel et al, } \\
2013\end{array}$ & USA & 48 & 113 & Saliva & $\mathrm{S}, \mathrm{M}$ & qMSP & DCC,EDNRB \\
\hline $\begin{array}{l}\text { Ovchinnikov et al, } \\
2012\end{array}$ & Australia & 143 & 31 & Saliva & M & MSP & $\begin{array}{l}\text { RASSF1A, } \\
\text { p16,DAPK1 }\end{array}$ \\
\hline Minor et al, 2012 & USA & 59 & 48 & Tissue & $\mathrm{S}, \mathrm{M}$ & MSP & miR-9-1,miR-9-3 \\
\hline Nagata et al, 2012 & Japan & 34 & 24 & Saliva & $\mathrm{S}$ & MSP & $\begin{array}{l}\text { ECAD, TMEFF2, } \\
\text { RAR } \beta, \text { MGMT, } \\
\text { FHIT, WIF-1, } \\
\text { DAPK, p16, HIN- } \\
\text { 1, TIMP3, p15, } \\
\text { APC, SPARC }\end{array}$ \\
\hline Zhange et al, 2012 & Sweden & 49 & 20 & Tissue & $\mathrm{S}$ & MSP & $\begin{array}{l}\text { EBNA1, LMP1, } \\
\text { RASSF1A, DAPK }\end{array}$ \\
\hline $\begin{array}{l}\text { Demokan et al, } \\
2011\end{array}$ & Turkish & 60 & 77 & Tissue & $\mathrm{S}$ & MSP & P16 \\
\hline Li et al, 2011 & China & 47 & 15 & Tissue & $\mathrm{S}, \mathrm{M}$ & MSP & $\begin{array}{l}\text { P16, DAPK, } \\
\text { RARb, CDH1, } \\
\text { RASSF1A } \\
\text { (Continued) }\end{array}$ \\
\hline
\end{tabular}




\begin{tabular}{|c|c|c|c|c|c|c|c|}
\hline Study & Country & Case\# & Control\# & Sample & Biomarker & Technique & Methylated genes \\
\hline Weiss et al, 2011 & Germany & 51 & 31 & Tissue & $\mathrm{S}$ & MSP & P16 \\
\hline Gyobu et al, 2011 & Japan & 40 & 8 & Tissue & $\mathrm{S}$ & qMSP & $\begin{array}{c}\text { PAX6, } \\
\text { ENST00000363328 }\end{array}$ \\
\hline Loyo et al, 2011 & $\begin{array}{l}\text { Hong } \\
\text { Kong }\end{array}$ & 50 & 28 & Tissue & $\mathrm{S}, \mathrm{M}$ & qMSP & $\begin{array}{c}\text { AIM1, APC, } \\
\text { CALCA, DCC, } \\
\text { DLEC, DLC1, } \\
\text { ESR, FHIT, } \\
\text { KIF1A, PGP9.5, } \\
\text { TIG1 }\end{array}$ \\
\hline $\begin{array}{l}\text { Guerrero-Preston } \\
\text { et al, } 2011\end{array}$ & USA & 24 & 12 & Tissue, Saliva & $\mathrm{S}$ & $\begin{array}{l}\text { BeadChip, } \\
\text { qMSP }\end{array}$ & $\begin{array}{l}\text { HOXA9, NID2, } \\
\text { GATA4, KIF1A, } \\
\text { EDNRB, DCC, } \\
\text { MCAM, CALCA }\end{array}$ \\
\hline $\begin{array}{l}\text { Laytragoon et al, } \\
2010\end{array}$ & Sweden & 41 & 18 & Tissue & $\mathrm{S}$ & MSP & P16 \\
\hline Pattani et al, 2010 & USA & 48 & 113 & Saliva & $\mathrm{S}$ & qMSP & EDNRB \\
\hline Kaur et al, 2010 & India & 92 & 48 & Tissue, blood & $\mathrm{S}$ & qMSP & P16 \\
\hline Tawfik et al, 2010 & Egypt & 34 & 15 & Tissue & $\mathrm{S}$ & MSP & hMLH1 \\
\hline Su et al, 2010 & Taiwan & 30 & 30 & Tissue & $\mathrm{S}$ & qMSP & P16 \\
\hline Cao et al, 2009 & China & 22 & 56 & Tissue & $\mathrm{S}$ & MSP & P16 \\
\hline $\begin{array}{l}\text { Steinmann et al, } \\
2009\end{array}$ & Germany & 54 & 23 & Tissue & $\mathrm{S}$ & MSP & P16 \\
\hline Ghosh et al, 2009 & India & 63 & 40 & Tissue & $\mathrm{S}$ & MSRA & India \\
\hline Viet et al, 2008 & USA & 13 & 23 & Tissue, saliva & M & BeadChip & $\begin{array}{c}\text { GABRB3, IL11, } \\
\text { INSR, NOTCH3, } \\
\text { NTRK3, PXN, } \\
\text { ERBB4, PTCH2, } \\
\text { TMEFF1, } \\
\text { TNFSF10, } \\
\text { TWIST1, } \\
\text { ADCYAP1, } \\
\text { CEBPA, EPHA5, } \\
\text { FGF3, HLF, } \\
\text { AGTR1, BMP3, } \\
\text { FGF8, NTRK3, } \\
\text { FLT, IRAK3, KDR, } \\
\text { NTRK, RASGRF1, } \\
\text { WT1, ESR1, } \\
\text { ETV1, GAS7, } \\
\text { PKD2, WNT2, } \\
\text { EPHA5, GALR1, } \\
\text { KDR, p16, AGTR1, } \\
\text { EYA4, IHH, } \\
\text { NTRK3, NTRK3, } \\
\text { TFPI2 } \\
\text { (Continued) }\end{array}$ \\
\hline
\end{tabular}




\begin{tabular}{|c|c|c|c|c|c|c|c|}
\hline Study & Country & Case\# & Control\# & Sample & Biomarker & Technique & Methylated genes \\
\hline Adams et al, 2008 & USA & 51 & 50 & Tissue, blood & $\mathrm{S}, \mathrm{M}$ & qMSP & $\begin{array}{c}\text { AHRR, p16, CBRP, } \\
\text { CLDN3, MT1G, } \\
\text { MGMT, RAR } \beta, \\
\text { PGP9.5 }\end{array}$ \\
\hline $\begin{array}{l}\text { Carvalho et al, } \\
2008\end{array}$ & USA & 135 & 462 & Tissue, saliva & S & qMSP & $\begin{array}{c}\text { DCC, DAPK, ESR, } \\
\text { CCNA1, CCND2, } \\
\text { MINT1, MINT31, } \\
\text { CDH1, AIM1, } \\
\text { MGMT, p16, } \\
\text { PGP9.5, RAR } \beta, \\
\text { HIC1, RASSF1A, } \\
\text { CALCA, TGFBR2, } \\
\text { S100A2, RIZ1, } \\
\text { RBM6 }\end{array}$ \\
\hline $\begin{array}{l}\text { Righimi et al, } \\
2007\end{array}$ & French & 90 & 30 & Tissue, saliva & S & MSP & P16 \\
\hline $\begin{array}{l}\text { Franzmann et al, } \\
2007\end{array}$ & USA & 102 & 69 & Saliva & S & MSP & CD44 \\
\hline $\begin{array}{l}\text { Martone et al, } \\
2007\end{array}$ & Italy & 20 & 11 & Tissue & S & MSP & P16 \\
\hline Shaw et al, 2006 & UK & 80 & 26 & Tissue & S & Pyro & P16 \\
\hline Maruya et al, 2004 & USA & 14 & 32 & Tissue & $\mathrm{S}$ & MSP & P16 \\
\hline $\begin{array}{l}\text { Kulkarni et al, } \\
2004\end{array}$ & India & 60 & 60 & Tissue, saliva & S & MSP & P16 \\
\hline Weber et al, 2003 & Germany & 50 & 42 & Tissue & S & MSP & P16 \\
\hline Wong et al, 2003 & China & 73 & 29 & Tissue, blood & $\mathrm{S}$ & MSP & P16 \\
\hline Tong et al, 2002 & $\begin{array}{l}\text { Hong } \\
\text { Kong }\end{array}$ & 28 & 26 & Tissue & S & MSP & EBV \\
\hline $\begin{array}{l}\text { Nakahara et al, } \\
2001\end{array}$ & Japan & 32 & 32 & Tissue & $\mathrm{S}$ & MSP & P16 \\
\hline Rosas et al, 2001 & USA & 30 & 30 & Saliva & S & MSP & P16 \\
\hline $\begin{array}{l}\text { Sanchez et al, } \\
2000\end{array}$ & USA & 95 & 26 & Blood & $\mathrm{S}$ & MSP & P16 \\
\hline
\end{tabular}

$\mathrm{S}$ represented single methylated gene as diagnostic marker, and $\mathrm{M}$ represented combination of multiple methylated genes as diagnostic marker.

separately for the saliva, solid tissue, and blood samples. DNA methylation detected from saliva samples had an overall sensitivity and specificity for $\mathrm{HNC}$ diagnosis of 0.47 (95\% CI: 0.39-0.55) and 0.89 (95\% CI: 0.85-0.91), respectively (Figure 2A). In solid tissue samples the overall sensitivity and specificity were 0.57 (95\% CI: 0.50 0.63 ) and 0.88 (95\% CI: 0.84-0.9), respectively (Figure
2B). Blood samples provided the lowest overall sensitivity at 0.46 (95\% CI: $0.32-0.61)$, and overall specificity of 0.85 (95\% CI: 0.77-0.91, Figure 2C).

In addition, we evaluated the diagnostic power based on the types of methylation biomarkers. The single methylation markers had overall sensitivity and specificity of 0.51 (95\% CI: $0.45-0.57)$ and 0.87 (95\% CI: $0.84-$ 
Table 2: Heterogeneity analysis of diagnostic effects

\begin{tabular}{lccccccc}
\hline Sample & Effects & Estimate[95\% CI] & Log(Estimate) $[\mathbf{9 5 \%}$ CI] & df & Q & P-value & $\mathbf{I}^{2}$ \\
\hline All & PLR & $3.45[3.07-3.88]$ & $1.24[1.12-1.35]$ & 207 & 257.16 & 0.01 & $19.51 \%$ \\
& NLR & $0.62[0.59-0.64]$ & $-0.48[-0.52$ to -0.44$]$ & 207 & 578.57 & $<0.01$ & $64.22 \%$ \\
& DOR & $7.84[6.56-9.35]$ & $2.06[1.88-2.24]$ & 207 & 242.98 & 0.044 & $14.81 \%$ \\
\multirow{3}{*}{ Saliva } & PLR & $3.60[2.97-4.37]$ & $1.28[1.09-1.47]$ & 75 & 63.44 & 0.827 & $0 \%$ \\
& NLR & $0.71[0.67-0.74]$ & $-0.35[-0.40$ to -0.30$]$ & 75 & 290.26 & $<0.01$ & $74.16 \%$ \\
& DOR & $6.84[5.45-8.59]$ & $1.92[1.70-2.75]$ & 75 & 106.90 & 0.01 & $29.84 \%$ \\
\multirow{3}{*}{ Tissue } & PLR & $3.85[3.08-4.83]$ & $1.35[1.13-1.57]$ & 70 & 81.91 & 0.156 & $14.54 \%$ \\
& NLR & $0.52[0.47-0.57]$ & $-0.66[-0.76$ to -0.56$]$ & 70 & 117.57 & $<0.01$ & $40.46 \%$ \\
& DOR & $10.96[7.57-15.89]$ & $2.40[2.02-2.77]$ & 70 & 68.33 & 0.534 & $0 \%$ \\
\multirow{3}{*}{ Blood } & PLR & $2.76[1.89-4.03]$ & $1.01[0.63-1.39]$ & 10 & 10.26 & 0.418 & $2.57 \%$ \\
& NLR & $0.65[0.54-0.78]$ & $-0.43[-0.61$ to -0.25$]$ & 10 & 15.19 & 0.125 & $34.17 \%$ \\
& DOR & $5.42[2.98-9.86]$ & $1.69[1.09-2.29]$ & 10 & 8.28 & 0.60 & $0 \%$ \\
\hline
\end{tabular}

PLR: positive likelihood ratio. NLR: negative likelihood ratio. DOR: diagnostics odd ratio. Estimate [95\% CI]: the pooled effect measure with the corresponding 95\% confidence interval. Log (Estimate) [95\% CI]: logarithmic transformation of the pooled effect measure with the corresponding 95\% confidence interval. df: degrees of freedom. Q and P-value were the Q value and $p$ value of Cochran's $Q$ test.

Table 3: Meta-regression analysis

\begin{tabular}{lcccc}
\hline \multirow{2}{*}{ Factor } & \multicolumn{2}{c}{ Sensitivity } & \multicolumn{2}{c}{ False positive rate } \\
\cline { 2 - 5 } & Coefficient & p value & Coefficient & p value \\
\hline Year & 0.132 & 0.070 & 0.018 & 0.559 \\
Marker type & 0.15 & 0.489 & -0.193 & 0.379 \\
Technique & -0.185 & 0.051 & -0.023 & 0.824 \\
Sample & 0.068 & 0.345 & 0.098 & 0.186 \\
\hline
\end{tabular}

$0.90)$, respectively. The diagnostic sensitivity of multiple methylation markers was 0.55 (95\% CI: $0.47-0.63)$ and the specificity was 0.88 (95\% CI: $0.85-0.90)$. In general, methylated biomarkers showed differential diagnostic accuracy in all three sample types, and the diagnostic power of integrating multiple methylated genes was better than with a single gene.

According to the sensitivity and specificity results from each trial, the regression coefficients of the SROC curves were near 0 for the three sample types (Table 4). The AUC curve indicated that samples from solid tissue had the highest diagnostic accuracy, with an AUC value of 0.82 (Figure 3) and a $Q^{*}$ metric of 0.81 (95\% CI: $0.77-0.85$ ), whereas the sensitivity was identical to the specificity (Table 4, Figure 3). In addition, the panel of multiple methylated genes showed higher AUC value than a single methylated gene $(0.85$ vs. 0.77$)$. These results suggest that the combination of multiple methylation biomarkers in solid tissue has better diagnostic accuracy, with higher sensitivity in saliva, which could be useful for HNC screening.

\section{Publish bias and sensitivity analysis}

The risk of bias for each study was first assessed (Supplementary Figure 1). As shown in Figure 4, 92\% of studies showed a low or unclear risk of bias for many bias items and only $5 \sim 18 \%$ of studies clearly reported a non- 
A

Author[Biomarker]

Sensitivity [95\% CI]

Specificity $[95 \% \mathrm{CI}]$

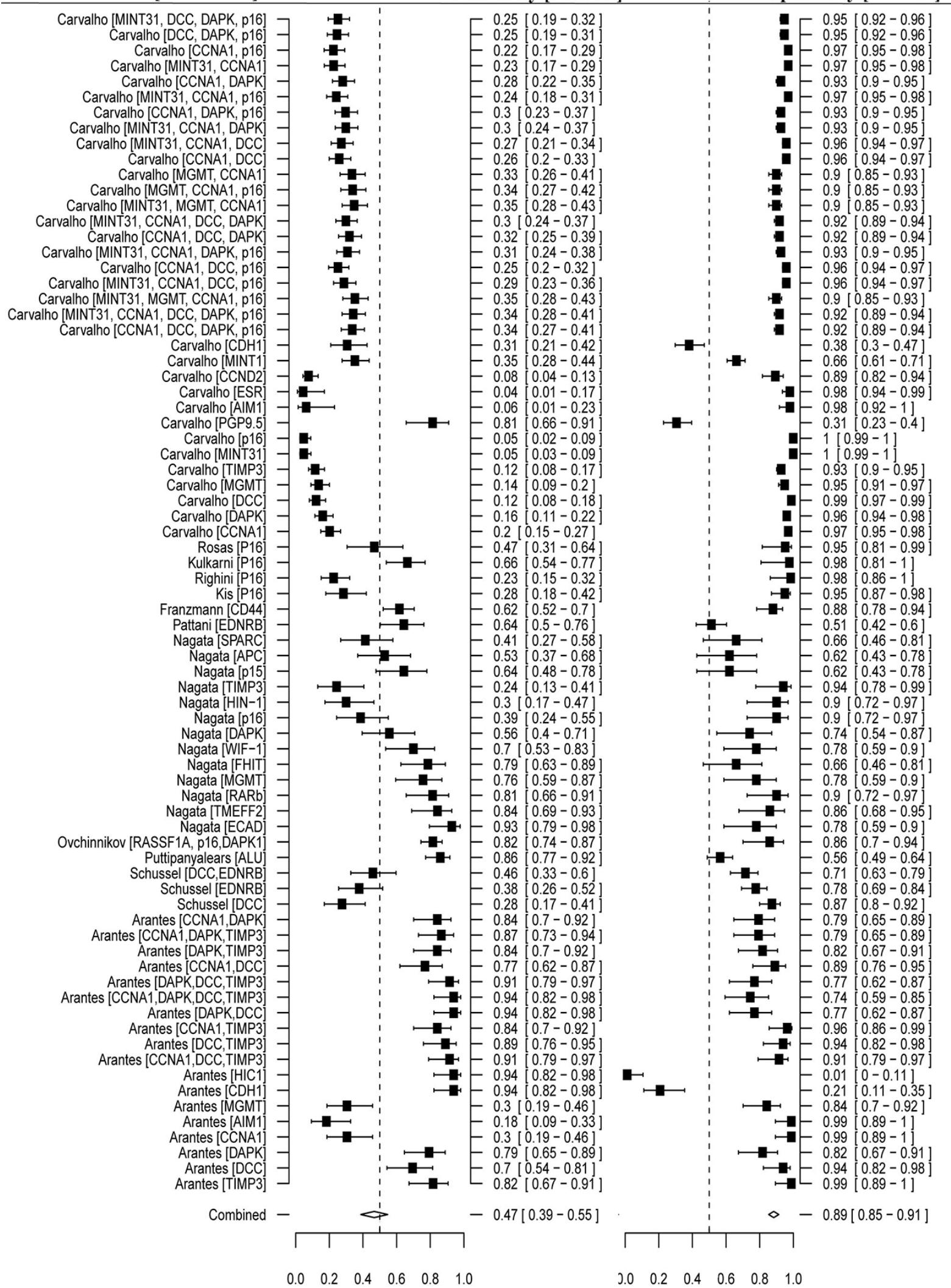

Figure 2: Forest plot of estimate of diagnostic accuracy using methylated biomarkers. A. Forest plot of estimate of sensitivity and specificity of methylated biomarkers in saliva.

(Continued) 


\section{B}

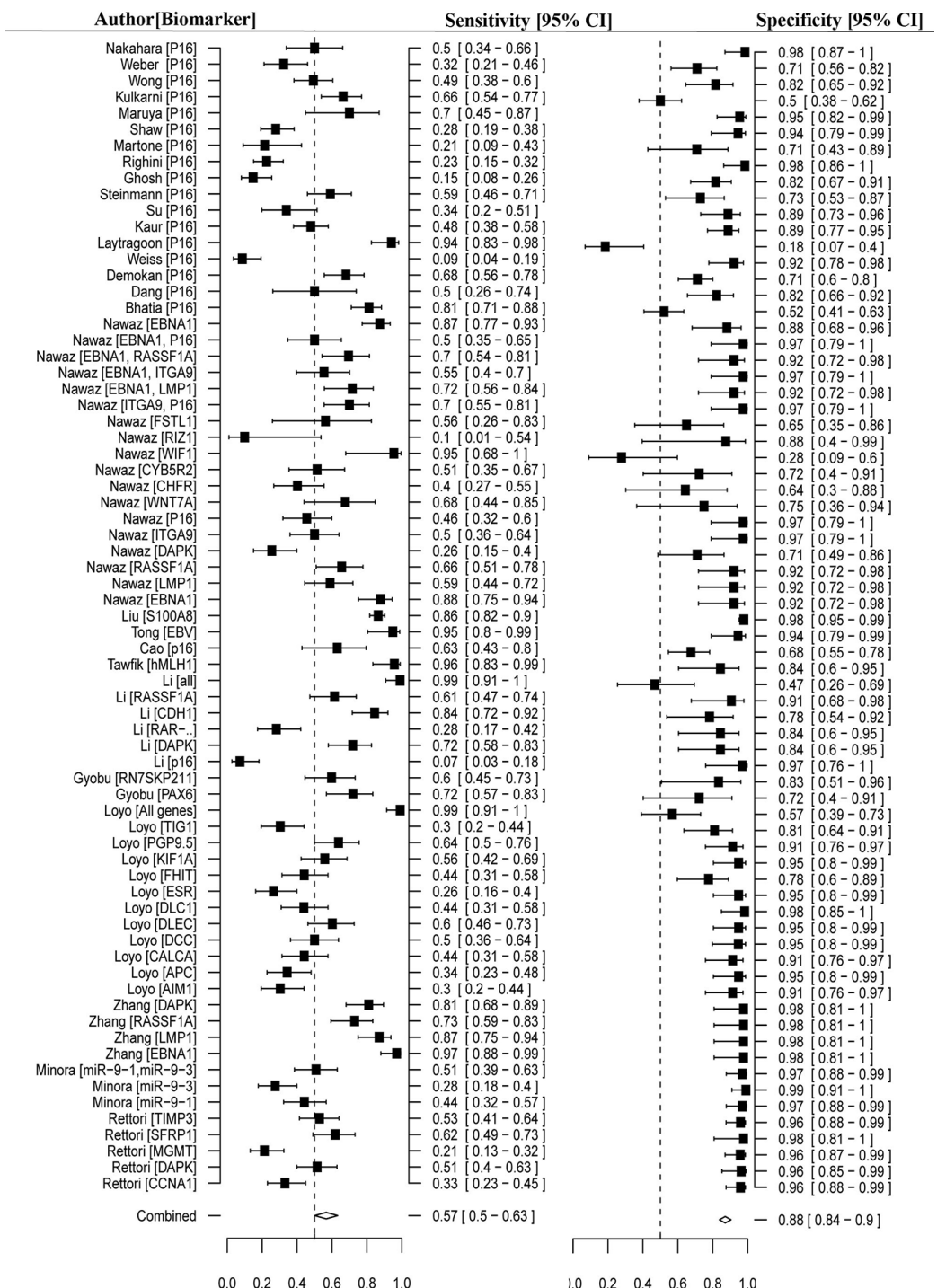

$\mathrm{C}$

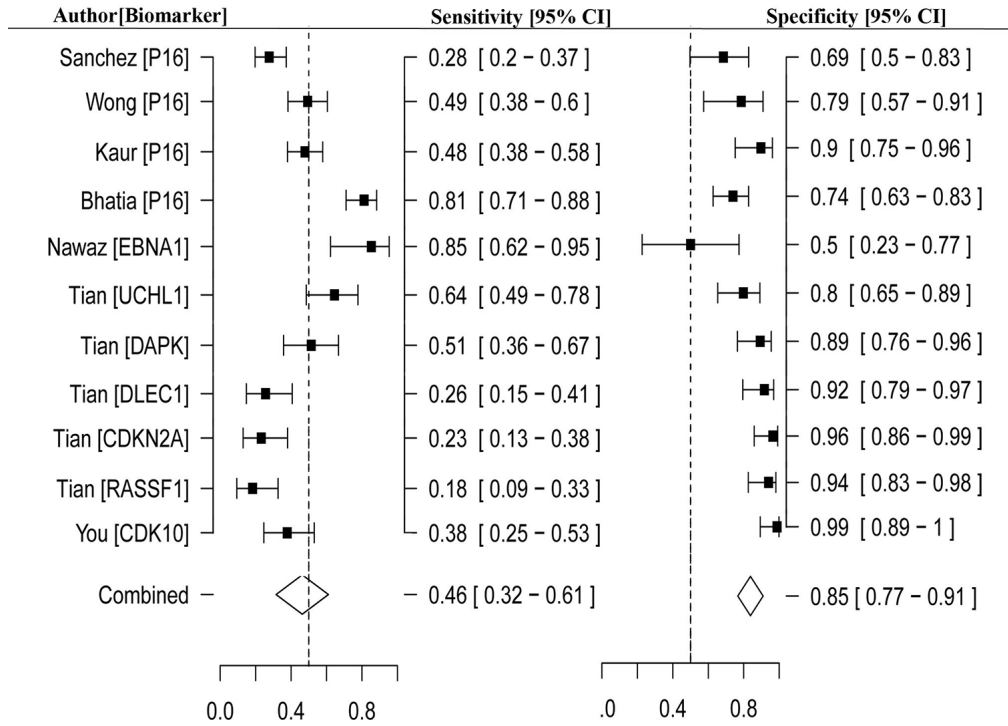

Figure 2 (Continued): B. Forest plot of estimate of sensitivity and specificity of methylated biomarkers in tissue. C. Forest plot of estimate of sensitivity and specificity of methylated biomarkers in blood. 
Table 4: The main analysis results of SROC

\begin{tabular}{lcccccc}
\hline Sample & Sensitivity (95\% CI) & Specificity (95\% CI) & a (95\% CI) & b (95\% CI) & AUC & Q* (95\% CI) \\
\hline Saliva & $0.47(0.39-0.55)$ & $0.89(0.85-0.91)$ & $2.14(1.71-2.56)$ & $-0.02(-0.14-0.09)$ & 0.80 & $0.74(0.70-0.78)$ \\
Tissue & $0.57(0.5-0.63)$ & $0.88(0.84-0.90)$ & $2.91(2.37-3.44)$ & $0.07(-0.11-0.25)$ & 0.82 & $0.81(0.77-0.85)$ \\
Blood & $0.46(0.32-0.61)$ & $0.85(0.77-.91)$ & $1.75(0 ., 74-2.77)$ & $-0.09(-0.42-0.24)$ & 0.77 & $0.71(0.59-0.80)$ \\
\hline
\end{tabular}

Sensitivity and Specificity represent the independent pooled sensitivity (Se) and specificity (Sp) using fixed effect model. $a$ and $b$ represent the intercept and slope of SROC curve. AUC represent the area under SROC curve. Q* represents the diagnostic threshold at which the probability of a correct diagnosis is constant for all subjects and calculated as exp(a/2)/ $[1+\exp (\mathrm{a} / 2)]$.

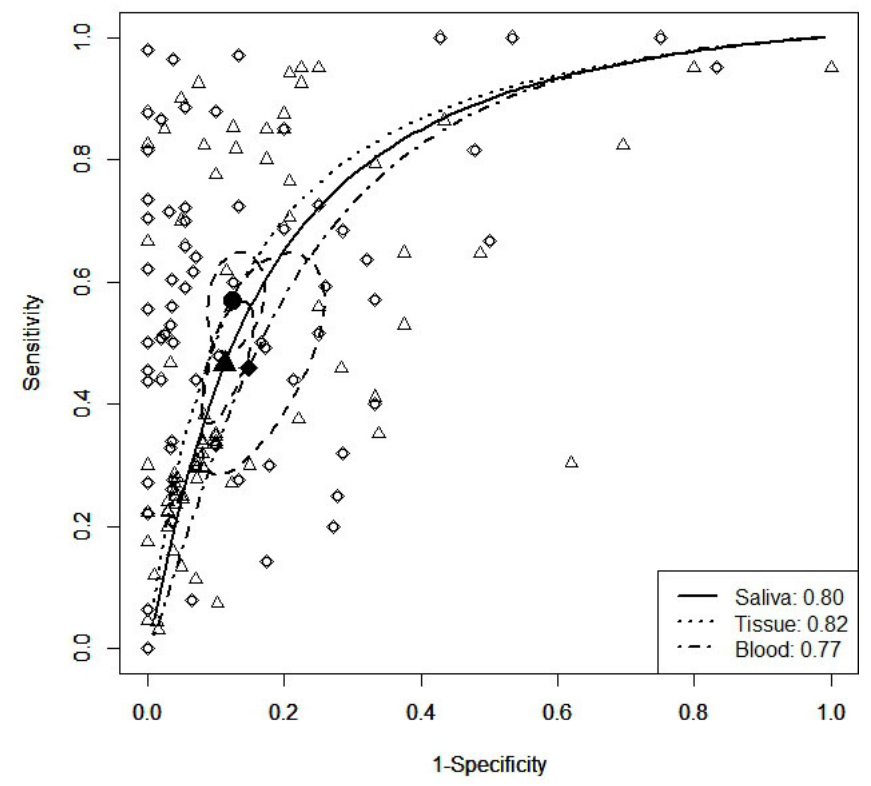

Figure 3: SROC curves of studies relating to the detection of HNC in different biopsy types.

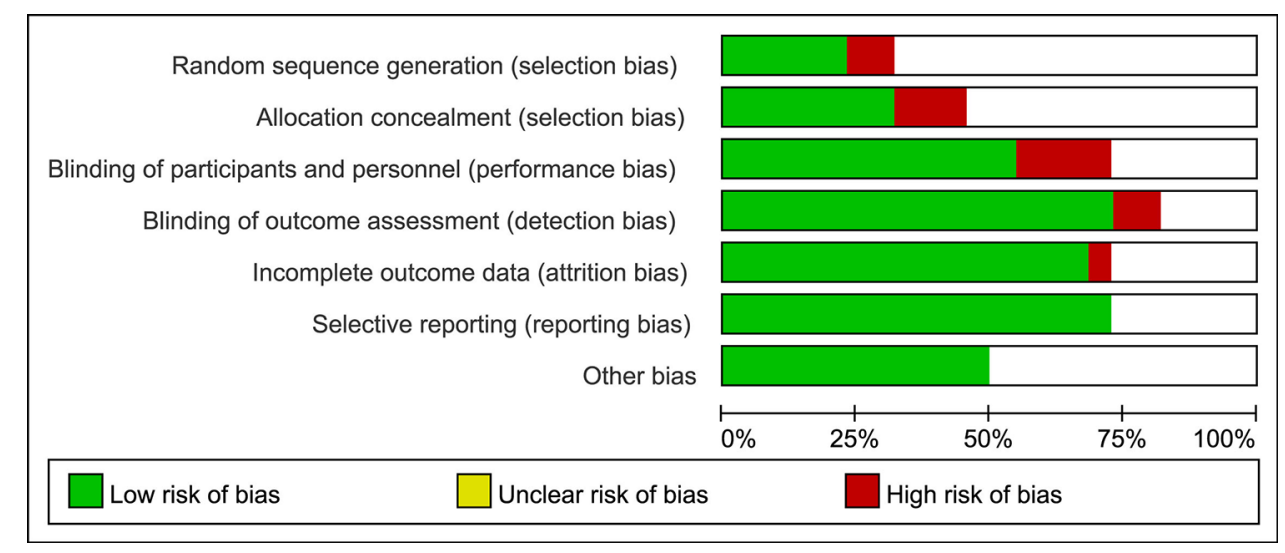

Figure 4: Risk of bias graph. Two authors independently evaluated the items of bias. If the study reported all of the sensitivities and specificities of genes that were measured DNA methylation status, selective reporting was defined as low risk. 
random sequence generation, no blinding, or incomplete blinding. More than $50 \%$ of the studies had independent data collection, assessment of DNA methylation, and interpretation of outcomes. In total, $75 \%$ of the studies show the sensitivities and specificities for all of the evaluated methylation biomarkers, which suggested no selective reporting. Ten studies were reported to be free of other sources of bias. Based on these metrics we deemed the quality of the studies included in the following metaanalysis to be acceptable.

By testing the relationship between the DOR and its standard error, we assessed the publication bias effects of the sample size for each diagnostic consequence. The potential publication bias was ascertained in these studies using symmetrical funnel plots for the saliva, solid tissue, and blood samples. We found that some studies corresponding to saliva (Figure 5A) or solid tissue (Figure 5B) were not inside the funnel. Begg's testing demonstrated that there was no significant publication bias in the three sample types from HNC patients. The studies with smaller sample sizes did not tend towards higher levels of accuracy.

A one-way sensitivity analysis was performed to evaluate the robustness of the results of this meta-analysis with respect to study and biomarker. The pooled specificity was not influenced when removing one study or diagnostic biomarker (Supplementary Table 2, 3). The sensitivity was increased when the studies by Carvalho et al. and Adams et al. were excluded, and was decreased when the study by Arantes et al. was excluded (Supplementary Table 2). The exclusion of individual methylated markers had no effect on diagnostic sensitivity.

\section{DISCUSSION}

DNA methylation has previously been demonstrated to be a potentially useful marker for multiple cancers [52].
Abnormally methylated regions in cancer-related genes such as RASSF1A [24], p16[53], RAR- $\beta$ [24], and MGMT [54], provide adequate sensitivity and specificity for the detection of HNC. Other abnormally methylated genes have shown inconsistent diagnostic accuracy for HNC. For example, the sensitivity of $p 16$ for diagnosing $\mathrm{HNC}$ varied from $44.6 \%$ to $100 \%[19,55]$.

In this study, we analyzed the accuracy of methylated genes for diagnosing $\mathrm{HNC}$ based on previously published studies. Overall, the sensitivity of the DNA methylation was 0.47 in saliva, 0.57 in solid tissue and 0.46 in blood, and the specificity was $0.89,0.88$ and 0.85 , respectively. We found that DNA methylation had low sensitivity but high specificity in the diagnosis of HNC. Different samples showed similar specificity but differential sensitivity. Seven papers corresponding to eleven studies were used to estimate the diagnostic accuracy of DNA methylation in blood. The small number of studies may provide misleading conclusions on the diagnostic power in blood that should be further evaluated. Moreover, testing for multiple methylated genes showed higher sensitivity than single methylated genes. Ideally, we should assess the overall diagnostic accuracy of the same combinations of methylated genes or single genes in three different sample types, but were limited by the number of studies available in the literature. We provide detailed information on the combinations of multiple methylated genes in Figure 2. Behind each author's name is the applicable DNA methylation marker information for the specific study. The evidence from this study suggests that DNA methylation biomarkers might be effective tools for detecting HNC. It should also be noted that the diagnostic accuracy of DNA methylation depends on the sample type and diagnostic markers studied.

Many of the studies in our analysis detected DNA methylation based on methylation-specific PCR (MSP), one of the principle methods of investigating DNA
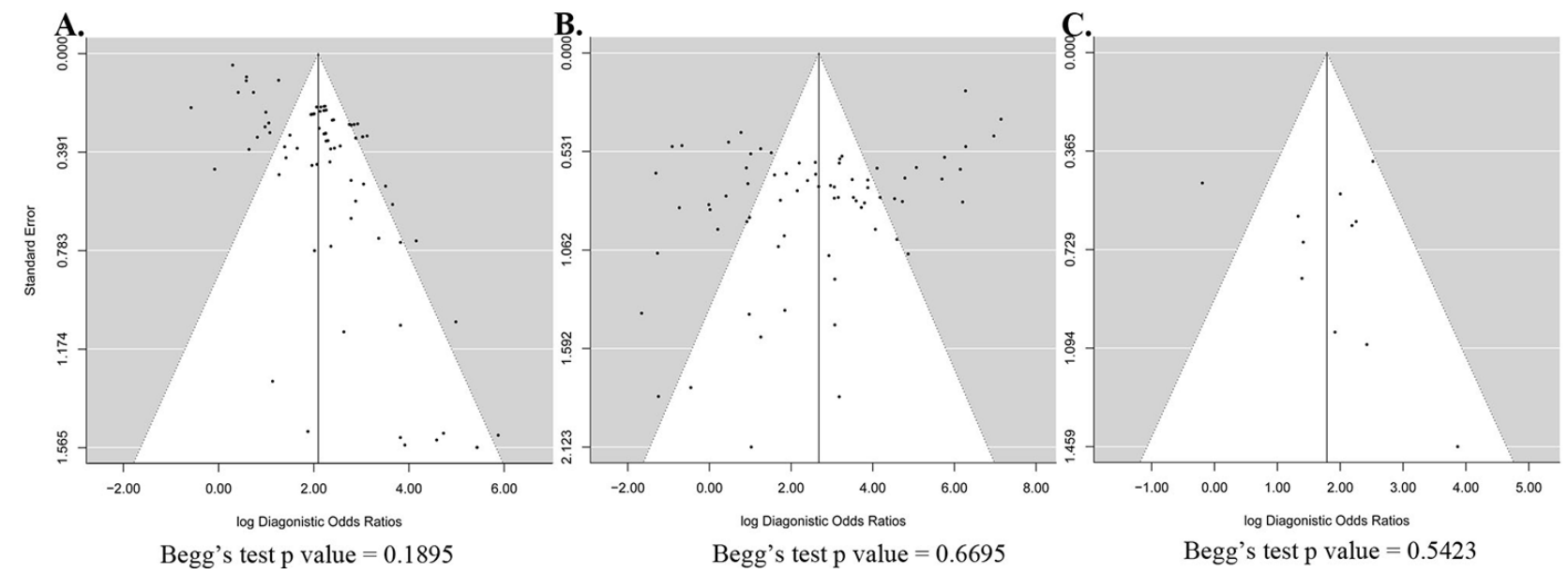

Figure 5: Funnel plot to assess bias in estimates of diagnostic odds ratio caused by small-study effects. A. Saliva. B. Solid tissue. C. Blood. 
methylation. MSP typically overestimates the extent of methylation, which would affect the diagnosis of HNC. We studied whether the assay method of DNA methylation affects the HNC diagnosis, but found no significant differences among these methods.

\section{MATERIALS AND METHODS}

\section{Data sources and search strategy}

We searched for diagnostic studies in PubMed published before July 2016. The search strategy for PubMed was ("head and neck neoplasms" [MeSH Terms] OR "head and neck cancer" [All Fields]) AND ("sensitivity and specificity"[MeSH Terms] OR "sensitivity and specificity" [All Fields] AND ("DNA methylation" [MeSH Terms] OR "DNA methylation" [All Fields]) to find appropriate studies published in English prior to July 25, 2016. We searched for published trials that evaluated the diagnostic accuracy of one or more methylated biomarkers. In addition, we added all studies included in a previous meta-analysis into our analysis [56].

\section{Study selection}

Two reviewers independently filtered the search results by the title and abstract. Studies were excluded if they did not pertain to DNA methylation, were not related to $\mathrm{HNC}$, were not diagnostic studies, or were reviews. Two authors obtained the full text of each paper and further filtered out the studies that did not supply sensitivity or specificity data for HNC diagnosis or that concerned the diagnosis of recurrence. We collected the authors' names; institutions; publication dates; sample types, including saliva, solid tissue, and blood; methylated biomarkers; and techniques of DNA methylation detection for all of the studies. All studies were evaluated independently and discussed by the authors until any inconsistencies were resolved.

\section{Data extraction and quality assessment}

A standardized data extraction form was used to extract the information from each paper including the first author, year of publication, country in which the study was performed, number of cases and controls, sample types, methylated gene names, DNA methylation detection techniques, number of methylated genes used as diagnostic biomarkers, and records of true positive, false positive, true negative and false negative results in head and neck cancer. Simultaneously, we evaluated the risk of bias according to pre-specified criteria from the Cochrane Collaboration's tool for assessing the risk of bias [57]. The two authors independently checked the risk of bias assessment for each trial using standardized methods including the following (Supplementary Table 4): whether a study showed selection bias including sequencing generation and allocation concealment; whether the performance was biased regarding the blinding of patients and study personnel; whether the detection was biased according to the assessment of the blinding of the outcome; and whether the attrition and reporting were biased by being based on incomplete outcome data and selective reporting, respectively.

\section{Data synthesis and statistical analysis}

We extracted the number of true positive (TP), false positive (FP), true negative (TN) and false negative (FN) results based on the remaining studies. The summary effects of the positive likelihood ratio (PLR), negative likelihood ratio (NLR), diagnostic odds ratio (DOR), and 95\% confidence intervals (CI) were further computed to estimate the statistical heterogeneities through Cochran's Q test, that approximately follows a $\chi^{2}$ distribution with $\mathrm{k}-1$ degrees of freedom (where $\mathrm{k}$ is the number of included studies) [58]. We assessed $\mathrm{I}^{2}$ $=((\mathrm{Q}-(\mathrm{k}-1)) / \mathrm{Q}) \times 100 \%$, which ranged from $0-100 \%$. $\mathrm{I}^{2}$ represents different degrees of heterogeneity, including low (0-25\%), moderate (25-50\%), high $(50-75 \%)$ and very high $(75-100 \%)$ [58]. The $p$ value of the heterogeneity test determined whether a fixed- or random-effects model was used to estimate the diagnostic effects, and the significance level of heterogeneity was considered to be 0.05 . The overall sensitivity and specificity were estimated to represent the diagnostic power of DNA methylation for the detection of head and neck cancer. For the overall diagnostic accuracy, an SROC curve was generated based on the sensitivity and specificity of each study using the equation $\mathrm{D}=\mathrm{a}+\mathrm{b} \times \mathrm{S}$, where $\mathrm{D}=\operatorname{logit}(\mathrm{Se})-\operatorname{logit}(1-\mathrm{Sp})$ $=\log (\mathrm{OR})$ and $\mathrm{S}=\operatorname{logit}(\mathrm{Se})+\operatorname{logit}(1-\mathrm{Sp})$ [59]. In the regression equation, $\mathrm{D}$ represents the diagnostic power of the methylated biomarkers, and $\mathrm{S}$ represents the threshold of the classification between positive and negative. Because the parameters $\mathrm{D}$ and $\mathrm{S}$ are from different studies, the values of the regression coefficient closer to 0 suggested less significant heterogeneity in various studies, which corresponds to diagnostic accuracy. The area under the SROC curve (AUC) value was estimated to measure the overall diagnostic power of DNA methylation in individual studies. In addition, $\mathrm{Q}^{*}$ $=\mathrm{Se}=1-\mathrm{Sp}$ was computed according to the regression equation of SROC, where $\mathrm{Se}=\exp (\mathrm{a} / 2) /[1+\exp (\mathrm{a} / 2)]$ and $1-\mathrm{Sp}=1 /[1+\exp (\mathrm{a} / 2)]$, which suggested that the diagnostic threshold for a correct diagnosis was constant for all of the subjects. Publication bias was evaluated using funnel plot analyses and Begg's and Egger's tests, with a significance level defined as 0.01 . We used the mada and metafor package in $\mathrm{R}$ to performed the statistical analysis [60]. 


\section{CONFLICTS OF INTEREST}

DTR: none; SO: Consulting: Novartis, BMS, MSD; KK: none; TYS: Honoraria: Astra Zeneca, Amgen, BMS, Innate, Jounce, SD; FK: none; IT: none; UK: Honoraria: AmGen, Astra Zeneca, BMS, Glycotope, GSK, Merck Serono, Merck/MSD, Pfizer, Research Support: Innate Pharma, Sirtec, Pfizer.

\section{DISCLOSURES}

The authors declare no conflicts of interest.

\section{Authors contribution}

$\mathrm{XJ}$ and HL conceived the hypothesis and revised the manuscript. CG and $\mathrm{XJ}$ searched the literature and extracted the data. XJ performed the meta-analysis and wrote the manuscript. HL and XJ filtered the literature.

\section{REFERENCES}

1. Shaikhibrahim Z, Offermann A, Halbach R, Vogel W, Braun M, Kristiansen G, Bootz F, Wenzel J, Mikut R, Lengerke C, Reischl M, Schrock A, Perner S. Clinical and Molecular Implications of MED15 in Head and Neck Squamous Cell Carcinoma. Am J Pathol. 2015; 185: p. 1114-22.

2. Chang HP, Sheen LY, Lei YP. The protective role of carotenoids and polyphenols in patients with head and neck cancer. J Chin Med Assoc. 2014.

3. Moore BA, Weber RS, Prieto V, El-Naggar A, Holsinger FC, Zhou X, Lee JJ, Lippman S, Clayman GL. Lymph node metastases from cutaneous squamous cell carcinoma of the head and neck. Laryngoscope. 2005; 115: p. 1561-7.

4. Brinkmann O, Kastratovic DA, Dimitrijevic MV, Konstantinovic VS, Jelovac DB, Antic J, Nesic VS, Markovic SZ, Martinovic ZR, Akin D, Spielmann N, Zhou H, Wong DT. Oral squamous cell carcinoma detection by salivary biomarkers in a Serbian population. Oral Oncol. 2011; 47: p. 51-5.

5. Fan CY. Epigenetic alterations in head and neck cancer: prevalence, clinical significance, and implications. Curr Oncol Rep. 2004; 6: p. 152-61.

6. Shaw R. The epigenetics of oral cancer. Int J Oral Maxillofac Surg. 2006; 35: p. 101-8.

7. Jeltsch A. Beyond Watson and Crick: DNA methylation and molecular enzymology of DNA methyltransferases. Chembiochem. 2002; 3: p. 274-93.

8. Carvalho AL, Jeronimo C, Kim MM, Henrique R, Zhang Z, Hoque MO, Chang S, Brait M, Nayak CS, Jiang WW, Claybourne Q, Tokumaru Y, Lee J, et al. Evaluation of promoter hypermethylation detection in body fluids as a screening/diagnosis tool for head and neck squamous cell carcinoma. Clin Cancer Res. 2008; 14: p. 97-107.

9. Ovchinnikov DA, Cooper MA, Pandit P, Coman WB, Cooper-White JJ, Keith P, Wolvetang EJ, Slowey
PD, Punyadeera C. Tumor-suppressor Gene Promoter Hypermethylation in Saliva of Head and Neck Cancer Patients. Transl Oncol. 2012; 5: p. 321-6.

10. Schussel J, Zhou XC, Zhang Z, Pattani K, Bermudez F, Jean-Charles G, McCaffrey T, Padhya T, Phelan J, Spivakovsky S, Brait M, Li R, Bowne HY, et al. EDNRB and DCC salivary rinse hypermethylation has a similar performance as expert clinical examination in discrimination of oral cancer/dysplasia versus benign lesions. Clin Cancer Res. 2013; 19: p. 3268-75.

11. Minor J, Wang X, Zhang F, Song J, Jimeno A, Wang XJ, Lu X, Gross N, Kulesz-Martin M, Wang D, Lu SL. Methylation of microRNA-9 is a specific and sensitive biomarker for oral and oropharyngeal squamous cell carcinomas. Oral Oncol. 2012; 48: p. 73-8.

12. Nagata S, Hamada T, Yamada N, Yokoyama S, Kitamoto S, Kanmura Y, Nomura M, Kamikawa Y, Yonezawa S, Sugihara K. Aberrant DNA methylation of tumor-related genes in oral rinse: a noninvasive method for detection of oral squamous cell carcinoma. Cancer. 2012; 118: p. 4298-308.

13. Guerrero-Preston R, Soudry E, Acero J, Orera M, MorenoLopez L, Macia-Colon G, Jaffe A, Berdasco M, Ili-Gangas C, Brebi-Mieville P, Fu Y, Engstrom C, Irizarry RA, et al. NID2 and HOXA9 promoter hypermethylation as biomarkers for prevention and early detection in oral cavity squamous cell carcinoma tissues and saliva. Cancer Prev Res (Phila). 2011; 4: p. 1061-72.

14. Franzmann EJ, Reategui EP, Pedroso F, Pernas FG, Karakullukcu BM, Carraway KL, Hamilton K, Singal R, Goodwin WJ. Soluble CD44 is a potential marker for the early detection of head and neck cancer. Cancer Epidemiol Biomarkers Prev. 2007; 16: p. 1348-55.

15. Loyo M, Brait M, Kim MS, Ostrow KL, Jie CC, Chuang AY, Califano JA, Liegeois NJ, Begum S, Westra WH, Hoque MO, Tao Q, Sidransky D. A survey of methylated candidate tumor suppressor genes in nasopharyngeal carcinoma. Int J Cancer. 2011; 128: p. 1393-403.

16. Gyobu K, Yamashita S, Matsuda Y, Igaki H, Niwa T, Oka D, Kushima R, Osugi H, Lee S, Suehiro S, Ushijima T. Identification and validation of DNA methylation markers to predict lymph node metastasis of esophageal squamous cell carcinomas. Ann Surg Oncol. 2011; 18: p. 1185-94.

17. Pattani KM, Zhang Z, Demokan S, Glazer C, Loyo M, Goodman S, Sidransky D, Bermudez F, Jean-Charles G, McCaffrey T, Padhya T, Phelan J, Spivakovsky S, et al. Endothelin receptor type B gene promoter hypermethylation in salivary rinses is independently associated with risk of oral cavity cancer and premalignancy. Cancer Prev Res (Phila). 2010; 3: p. 1093-103.

18. Zhang Z, Sun D, Hutajulu SH, Nawaz I, Nguyen Van D, Huang G, Haryana SM, Middeldorp JM, Ernberg I, Hu LF. Development of a non-invasive method, multiplex methylation specific PCR (MMSP), for early diagnosis of nasopharyngeal carcinoma. PLoS One. 2012; 7: p. e45908. 
19. Cao J, Zhou J, Gao Y, Gu L, Meng H, Liu H, Deng D. Methylation of p16 CpG island associated with malignant progression of oral epithelial dysplasia: a prospective cohort study. Clin Cancer Res. 2009; 15: p. 5178-83.

20. Adams L, Roth MJ, Abnet CC, Dawsey SP, Qiao YL, Wang GQ, Wei WQ, Lu N, Dawsey SM, Woodson K. Promoter methylation in cytology specimens as an early detection marker for esophageal squamous dysplasia and early esophageal squamous cell carcinoma. Cancer Prev Res (Phila). 2008; 1: p. 357-61.

21. You Y, Yang W, Wang Z, Zhu H, Li H, Lin C, Ran Y. Promoter hypermethylation contributes to the frequent suppression of the CDK10 gene in human nasopharyngeal carcinomas. Cell Oncol (Dordr). 2013; 36: p. 323-31.

22. Viet CT, Schmidt BL. Methylation array analysis of preoperative and postoperative saliva DNA in oral cancer patients. Cancer Epidemiol Biomarkers Prev. 2008; 17: p. 3603-11.

23. Rettori MM, de Carvalho AC, Longo AL, de Oliveira CZ, Kowalski LP, Carvalho AL, Vettore AL. TIMP3 and CCNA1 hypermethylation in HNSCC is associated with an increased incidence of second primary tumors. J Transl Med. 2013; 11: p. 316.

24. Li B, Wang B, Niu LJ, Jiang L, Qiu CC. Hypermethylation of multiple tumor-related genes associated with DNMT3b up-regulation served as a biomarker for early diagnosis of esophageal squamous cell carcinoma. Epigenetics. 2011; 6: p. 307-16.

25. Tong JH, Tsang RK, Lo KW, Woo JK, Kwong J, Chan MW, Chang AR, van Hasselt CA, Huang DP, To KF. Quantitative Epstein-Barr virus DNA analysis and detection of gene promoter hypermethylation in nasopharyngeal (NP) brushing samples from patients with NP carcinoma. Clin Cancer Res. 2002; 8: p. 2612-9.

26. Tawfik HM, El-Maqsoud NM, Hak BH, El-Sherbiny YM. Head and neck squamous cell carcinoma: mismatch repair immunohistochemistry and promoter hypermethylation of hMLH1 gene. Am J Otolaryngol. 2011; 32: p. 528-36.

27. Puttipanyalears C, Subbalekha K, Mutirangura A, Kitkumthorn N. Alu hypomethylation in smoke-exposed epithelia and oral squamous carcinoma. Asian Pac J Cancer Prev. 2013; 14: p. 5495-501.

28. Tian F, Yip SP, Kwong DL, Lin Z, Yang Z, Wu VW. Promoter hypermethylation of tumor suppressor genes in serum as potential biomarker for the diagnosis of nasopharyngeal carcinoma. Cancer Epidemiol. 2013; 37: p. 708-13.

29. Arantes LM, de Carvalho AC, Melendez ME, Centrone CC, Gois-Filho JF, Toporcov TN, Caly DN, Tajara EH, GoloniBertollo EM, Carvalho AL. Validation of methylation markers for diagnosis of oral cavity cancer. Eur J Cancer. 2015; 51: p. 632-41.

30. Liu K, Zhang Y, Zhang C, Zhang Q, Li J, Xiao F, Li Y, Zhang R, Dou D, Liang J, Qin J, Lin Z, Zhao D, et al. Methylation of S100A8 is a promising diagnosis and prognostic marker in hepatocellular carcinoma. Oncotarget. 2016; 7:56798-56810. doi: 10.18632/oncotarget.10792.

31. Nawaz I, Moumad K, Martorelli D, Ennaji MM, Zhou X, Zhang Z, Dolcetti R, Khyatti M, Ernberg I, Hu LF. Detection of nasopharyngeal carcinoma in Morocco (North Africa) using a multiplex methylation-specific PCR biomarker assay. Clin Epigenetics. 2015; 7: p. 89.

32. Kis A, Tatar TZ, Gall T, Boda R, Tar I, Major T, Redl P, Gergely L, Szarka K. Frequency of genetic and epigenetic alterations of p14ARF and p16INK4A in head and neck cancer in a Hungarian population. Pathol Oncol Res. 2014; 20: p. 923-9.

33. Bhatia V, Goel MM, Makker A, Tewari S, Yadu A, Shilpi P, Kumar S, Agarwal SP, Goel SK. Promoter region hypermethylation and mRNA expression of MGMT and p16 genes in tissue and blood samples of human premalignant oral lesions and oral squamous cell carcinoma. Biomed Res Int. 2014; 2014: p. 248419.

34. Laytragoon-Lewin N, Chen F, Castro J, Elmberger G, Rutqvist LE, Lewin F, Turesson I, Lundgren J. DNA content and methylation of p16, DAPK and RASSF1A gene in tumour and distant, normal mucosal tissue of head and neck squamous cell carcinoma patients. Anticancer Res. 2010; 30: p. 4643-8.

35. Steinmann K, Sandner A, Schagdarsurengin U, Dammann RH. Frequent promoter hypermethylation of tumor-related genes in head and neck squamous cell carcinoma. Oncol Rep. 2009; 22: p. 1519-26.

36. Shaw RJ, Liloglou T, Rogers SN, Brown JS, Vaughan ED, Lowe D, Field JK, Risk JM. Promoter methylation of P16, RARbeta, E-cadherin, cyclin A1 and cytoglobin in oral cancer: quantitative evaluation using pyrosequencing. Br J Cancer. 2006; 94: p. 561-8.

37. Maruya S, Issa JP, Weber RS, Rosenthal DI, Haviland JC, Lotan R, El-Naggar AK. Differential methylation status of tumor-associated genes in head and neck squamous carcinoma: incidence and potential implications. Clin Cancer Res. 2004; 10: p. 3825-30.

38. Nakahara Y, Shintani S, Mihara M, Ueyama Y, Matsumura T. High frequency of homozygous deletion and methylation of p16(INK4A) gene in oral squamous cell carcinomas. Cancer Lett. 2001; 163: p. 221-8.

39. Sanchez-Cespedes M, Esteller M, Wu L, Nawroz-Danish H, Yoo GH, Koch WM, Jen J, Herman JG, Sidransky D. Gene promoter hypermethylation in tumors and serum of head and neck cancer patients. Cancer Res. 2000; 60: p. 892-5.

40. Dang J, Bian YQ, Sun JY, Chen F, Dong GY, Liu Q, Wang XW, Kjems J, Gao S, Wang QT. MicroRNA-137 promoter methylation in oral lichen planus and oral squamous cell carcinoma. J Oral Pathol Med. 2013; 42: p. 315-21.

41. Demokan S, Chuang A, Suoglu Y, Ulusan M, Yalniz Z, Califano JA, Dalay N. Promoter methylation and loss of p16(INK4a) gene expression in head and neck cancer. Head Neck. 2012; 34: p. 1470-5. 
42. Weiss D, Basel T, Sachse F, Braeuninger A, Rudack C. Promoter methylation of cyclin A1 is associated with human papillomavirus 16 induced head and neck squamous cell carcinoma independently of p53 mutation. Mol Carcinog. 2011; 50: p. 680-8.

43. Kaur J, Demokan S, Tripathi SC, Macha MA, Begum S, Califano JA, Ralhan R. Promoter hypermethylation in Indian primary oral squamous cell carcinoma. Int J Cancer. 2010; 127: p. 2367-73.

44. Su PF, Huang WL, Wu HT, Wu CH, Liu TY, Kao SY. p16(INK4A) promoter hypermethylation is associated with invasiveness and prognosis of oral squamous cell carcinoma in an age-dependent manner. Oral Oncol. 2010; 46: p. 734-9.

45. Ghosh A, Ghosh S, Maiti GP, Sabbir MG, Alam N, Sikdar N, Roy B, Roychoudhury S, Panda CK. SH3GL2 and $\mathrm{CDKN} 2 \mathrm{~A} / 2 \mathrm{~B}$ loci are independently altered in early dysplastic lesions of head and neck: correlation with HPV infection and tobacco habit. J Pathol. 2009; 217: p. 408-19.

46. Martone T, Gillio-Tos A, De Marco L, Fiano V, Maule M, Cavalot A, Garzaro M, Merletti F, Cortesina G. Association between hypermethylated tumor and paired surgical margins in head and neck squamous cell carcinomas. Clin Cancer Res. 2007; 13: p. 5089-94.

47. Kulkarni V, Saranath D. Concurrent hypermethylation of multiple regulatory genes in chewing tobacco associated oral squamous cell carcinomas and adjacent normal tissues. Oral Oncol. 2004; 40: p. 145-53.

48. Wong TS, Man MW, Lam AK, Wei WI, Kwong YL, Yuen AP. The study of p16 and p15 gene methylation in head and neck squamous cell carcinoma and their quantitative evaluation in plasma by real-time PCR. Eur J Cancer. 2003; 39: p. 1881-7.

49. Weber A, Wittekind C, Tannapfel A. Genetic and epigenetic alterations of 9p21 gene products in benign and malignant tumors of the head and neck. Pathol Res Pract. 2003; 199: p. 391-7.

50. Rosas SL, Koch W, da Costa Carvalho MG, Wu L, Califano J, Westra W, Jen J, Sidransky D. Promoter hypermethylation patterns of p16, O6-methylguanine-DNAmethyltransferase, and death-associated protein kinase in tumors and saliva of head and neck cancer patients. Cancer Res. 2001; 61: p. 939-42.

51. Righini CA, de Fraipont F, Timsit JF, Faure C, Brambilla E, Reyt E, Favrot MC. Tumor-specific methylation in saliva: a promising biomarker for early detection of head and neck cancer recurrence. Clin Cancer Res. 2007; 13: p. 1179-85.

52. Chen H, Yu Y, Rong S, Wang H. Evaluation of diagnostic accuracy of DNA methylation biomarkers for bladder cancer: a systematic review and meta-analysis. Biomarkers. 2014; 19: p. 189-97.

53. Ikoma D, Ichikawa D, Ueda Y, Tani N, Tomita H, Sai S, Kikuchi S, Fujiwara H, Otsuji E, Yamagishi H. Circulating tumor cells and aberrant methylation as tumor markers in patients with esophageal cancer. Anticancer Res. 2007; 27: p. 535-9.

54. Hall GL, Shaw RJ, Field EA, Rogers SN, Sutton DN, Woolgar JA, Lowe D, Liloglou T, Field JK, Risk JM. p16 Promoter methylation is a potential predictor of malignant transformation in oral epithelial dysplasia. Cancer Epidemiol Biomarkers Prev. 2008; 17: p. 2174-9.

55. Pannone G, Rodolico V, Santoro A, Lo Muzio L, Franco R, Botti G, Aquino G, Pedicillo MC, Cagiano S, Campisi G, Rubini C, Papagerakis S, De Rosa G, et al. Evaluation of a combined triple method to detect causative HPV in oral and oropharyngeal squamous cell carcinomas: p16 Immunohistochemistry, Consensus PCR HPV-DNA, and In Situ Hybridization. Infect Agent Cancer. 2012; 7: p. 4.

56. Shi H, Chen X, Lu C, Gu C, Jiang H, Meng R, Niu X, Huang Y, Lu M. Association between P16INK4a promoter methylation and HNSCC: a meta-analysis of 21 published studies. PLoS One. 2015; 10: p. e0122302.

57. Higgins JPT GSe. Cochrane Handbook for Systematic Reviews of Interventions Version 5.1.0 [updated March 2011]. The Cochrane Collaboration. 2011.

58. Jiang Y, Zhang R, Zheng J, Liu P, Tang G, Lv H, Zhang L, Shang Z, Zhan Y, Lv W, Shi M. Meta-analysis of 125 rheumatoid arthritis-related single nucleotide polymorphisms studied in the past two decades. PLoS One. 2012; 7: p. e51571.

59. Zintzaras E, Germenis AE. Performance of antibodies against tissue transglutaminase for the diagnosis of celiac disease: meta-analysis. Clin Vaccine Immunol. 2006; 13: p. 187-92.

60. Thorlund K, Imberger G, Johnston BC, Walsh M, Awad T, Thabane L, Gluud C, Devereaux PJ, Wetterslev J. Evolution of heterogeneity (I2) estimates and their $95 \%$ confidence intervals in large meta-analyses. PLoS One. 2012; 7: p. e39471. 